DOI https://doi.org/10.30525/978-9934-26-073-5-1-30

\title{
ХУДОЖНІЙ ХРОНОТОП РОМАНУ «ОСТАННІ ІСТОРІЇ» ОЛЬГИ ТОКАРЧУК
}

\author{
Журба С. С. \\ кандидат філологічних наук, доцент, \\ доцент кафедри української та зарубіжної літератур \\ Криворізького державного педагогічного університету \\ м. Кривий Ріг, Дніпропетровська область, Украӥна
}

Сучасний роман презентує модель літературного хронотопу, яка актуалізується у просторовій множинності, відхиляючи лінійне сприйняття часу, відтворює здатність героя до паралельного існування в різних вимірах. Хронотопний континуум нелінійної прози реалізований через ретроспекцію, проспекцію, розшарування теперішнього часу, хронологічні стрибки. Прийом ретроспекції - пригадування подій, які передували моментові фабули, змістово пов'язаний із функціонуванням художнього часу та психологізмом. Зміщення часопросторових координат, ускладненість сюжету та нарації, деструкція тексту визначає жанрову дефініцію сучасного роману. Історична ретроспектива $\epsilon$ визначальною у жанрі роману в листах, епістолярного роману, мемуарного роману, роману-репортажу, роману-заповіту, роману-щоденника, романусповіді, роману «потоку свідомості». Вільне поводження письменників доби постмодернізму з часопростором стало об'єктом для конструювання і авторської гри з текстом.

Ольга Токарчук - одна 3 найвідоміших та найпопулярніших польських письменниць сучасності, лауреатка літературної премії «Ніке», Міжнародної Букерівської премії, Нобелівської премії (2018). Авторка оповідань, повістей та романів, серед яких найвідоміші «Мандрівка людей Книги» («Podróż ludzi Księgi»), «Е. Е.»(«Е. Е.»), «Правік та інші часи» («Prawiek i inne czasy»), «Гра на багатьох барабанчиках» («Gra na wielu bębenkach»), «Останні історії» («Ostatnie historie»), «Бігуни» («Bieguni»), «Веди свій плуг понад кістками мертвих» («Prowadź swój pług przez kości umarłych»), «Книги Якова» («Księgi Jakubowe»), топосом яких $\epsilon$ межова, погранична територія, детермінована змінами та переходом із одного часу в інший. Творчий доробок мисткині - це живий експеримент, історична правда людського буття, що оживає під iї пером. Переміщення в часі і просторі, мотив мандрів, 
подорожей, паломництва, пошук свого шляху у житті - провідні теми творчості Ольги Токарчук.

Роман «Останні історії» є знаковим твором, у якому акцентовано на проблемі самоідентичності та універсальності життя трьох жінок п'ятдесятичотирирічної Іди Мажец, іiі матері Параскеви та доньки Майї. Структурна організація роману «Останні історії» полягає у рівноправному звучанні голосу авторки i трьох героїнь, кожна 3 яких представляє свій погляд на світ; трьох часових площин, трьох окремих просторів - топосів, що дозволяє говорити про поліфонічність. Художня деформація часу у творі, його «ущільнення» та «інтенсифікація» простору відповідає засадам постмодернізму - грі з хронотопом.

Авторка у романі грає 3 художнім часопростором, ведучи мову в кожному з розділів від імені і про одну із героїнь: «Чистий край» - Іди (під час поїздки у село, де жили батьки, потрапляє в аварію, згадує минуле), «Парка» - Параскеви (живе у будинку на відшибі, згадує про життя з чоловіком), «Фокусник» - Маї (мандрує з сином). Непроста доля цих жінок взаємопов'язана і вплетена в історію країн, в яких живуть. Маленькі села в горах України та Польщі, Варшава і далекі острови Малайзії - топоси роману «Останні історії». Хронометром доби у романі суспільно-історичний і приватний час кожної 3 героїнь: події розгортаються від передвоєнних років і до початку ХХ століття. Авторка, об’єктивізуючи часопростір, проводить своїх героїнь «крізь браму хронотопу» (М. Бахтін), проглядає минуле крізь призму сьогодення. Історія трьох жінок (бабусі Даздраперми Снігурець, матері Віталії Козик та дочки Олесі), кожна з яких веде боротьбу за своє щастя, змальована у романі Володимира Лиса «Країна гіркої ніжності». Події у творі українського письменника передані через спогади героїнь, що зближує 3 твором Ольги Токарчук. Взаємодія історичного та приватного хронотопу, «взаємоперетікання» часових і просторових координат визначають характер оповіді та композицію твору. В основу творів Ольги Токарчук та Володимира Лиса покладений ретроспективний принцип зображення особи та дійсності.

Розширенню хронотопу у романі Ольги Токарчук сприяє ретроспекція, детермінована роздумами і спогадами Іди про дитинство, юність, батька та матір, дім, чоловіка, народження дочки, роботу; матері Параскеви про юність, одруження, відносини 3 російським офіцером, переїзд у Польщу, народження дітей, смерть чоловіка. Погляд у минуле покликаний осмислити концептуально важливі для Іди епізоди життя. Події виринають в пам'яті жінки одна за одною як у калейдоскопі, «поєднуються у нескінченні ланцюжки окремими деталями, асоціаціями, 
аналогіями» [3, с. 19]. Авторка через сповідь кожної героїні привідкриває завісу особистого життя, акцентуючи на радісних та трагічних моментах. Відправною точкою спогадів Іди $є$, на перший погляд, незначні речі чи події, але саме вони забезпечують каузальні зв'язки з минулим. Фрагменти життєвих історій персонажів об’єднані принципом «зворотної» та «наступної» хронології. Включення у текст ретроспекцій дозволяє зупинити наративний ланцюг, уповільнити художній час. Н. Копистянська зауважує, що у XX столітті зберігаються функції ретроспекції як «старту», але з'являється багато нових форм і поєднання хронологічної ретроспекції з асоціативною: «Остання набуває все більшого значення i функцій внаслідок усвідомлення того, що художній час, на відміну від реального, не є одноваріантним, що автор має владу над часом, може надати йому напрямок, швидкість, ритм, повторюваність, багатоваріантність, плавність, повноту чи уривчастість, фрагментарність» [2, с.180].

Знаковим у творі $є$ хронотоп дороги як повернення й переосмислення минулого, випробування, представлений авторкою як реальний, так $\mathrm{i}$ метафоричний, а через пов'язані з ним теми пошуку, втрати, зустрічі виконує сюжетотворчу функцію. Життя жінок - це подорож до себе та шлях до пізнання світу, складають каркас їх буття. Хронотоп мандрівки $\epsilon$ важливим в «Останніх історіях», адже героїні мандрують 3 різних причин, привносячи жіночі історії у фемінне прочитання подій і світу. Три покоління поєднує міфологічний образ дороги, яким починається i закінчується роман. Твір починається з поїздки Іди до будинку батьків, але жінка потрапляє в аварію, так і не здійснивши мрію побачити покинутий будинок свого дитинства. Подорожі у житті жінки відіграють важливе значення, адже вона гід, працює в великому екскурсійному бюро «Серце Свропи» («The Heart of Europe»). Трагічне навантаження несе в собі дорога в Польщу для Параскеви, адже тоді помирає іiї старша дочка. Із мотивом дороги пов'язаний мотив рідного дому, який у творі набуває символічного значення: Іда згадує, що мама декілька разів їздила «на схід обглядати покинуті місця», і ця мандрівка надавала їй сил: «мама поверталася 3 цих подорожей бадьора і ніби молодша. Чи їй справді вдавалося повернути час? Чи це був східний шабаш, на якому викликали минуле, i чи це завдяки йому на маминому обличчі з'являлась підступна усмішка?» [3, с. 21]. Майя, подорожуючи Малайзією, знайомиться з ії мешканцями, традиціями, вважає ії країною, «без спогадів. Край, де панують прості закони, яких не треба розуміти, тут час це хвиля, постає і зникає» [3, с. 162]. Покидаючи малазійські острови, вона відчуває себе у безпеці. На думку Т. Дзядевич, у творах письменниці мотив рідної землі «конструюється 3 поліфонії голосів, даючи 
нам різну перспективу бачення, причому авторка знову ж таки не надає преференції жодній із моделей буття» [1].

Ольга Токарчук у творі образ дороги осмислює на міфологічному рівні: Іда, Параскева, Майя в постійному пошуку себе, саме тому зовнішній прояв руху дорогою переданий через рух внутрішній, духовний. Проте духовні родинні зв'язки у жінок відсутні. Письменниця звертається до проблеми генетичної пам'яті, важливим маркером якої $є$ українська мова та релігійність. Параскева - українка за національністю, волею долі переїжджає з чоловіком-поляком у Польщу під час переселення після Другої світової війни (тут прочитується й історія бабусі Ольги Токарчук). За посередництвом часу реалізується простір: топос невеличкого хутора, де оселилися Параскева з чоловіком Петром є для неї чужим, вона не може призвичаїтися до нової місцевості, звичаїв поляків, укладу їх життя, як і чужою була для неї католицька релігія i відвідування костелу. Пошуки себе, власного щастя, кохання, генетичної пам’яті слугують інструментом виміру національної приналежності та матрицею ідентичності трьох жінок.

Часопростір роману Ольги Токарчук побудований за принципом зворотної і наступної хронології та поєднує приватні історії Іди, Параскеви та Майї. Часопросторові зміщення, фрагментарність, спогади у творі покликані увиразнити художню картину світу та акцентувати на жанровій природі тексту. Прийом ретроспекції у сюжетній канві роману «Останні історії» Ольги Токарчук, конструюючи хронотопний континуум, забезпечує поліфонічність звучання провідних тем твору: самоідентифікації, генетичної пам'яті, усвідомлення сенсу буття.

\section{Література:}

1. Дзядевич Т. Творчість Ольги Токарчук: Кілька крапок над «і» (Ч. II). URL: http://litakcent.com/2009/10/01/tvorchist-olhy-tokarchuk-kilkakrapok-nad-i-chastyna-ii/ (дата звернення: 18.04.2021)

2. Копистянська Н. Жанр, жанрова система у просторі літературознавства. Львів : ПАІС, 2005. 368 с.

3. Токарчук О. Останні історії / пер. $з$ пол. Ярини Сенчишин. Львів: Літопис, 2007. 166 с. 